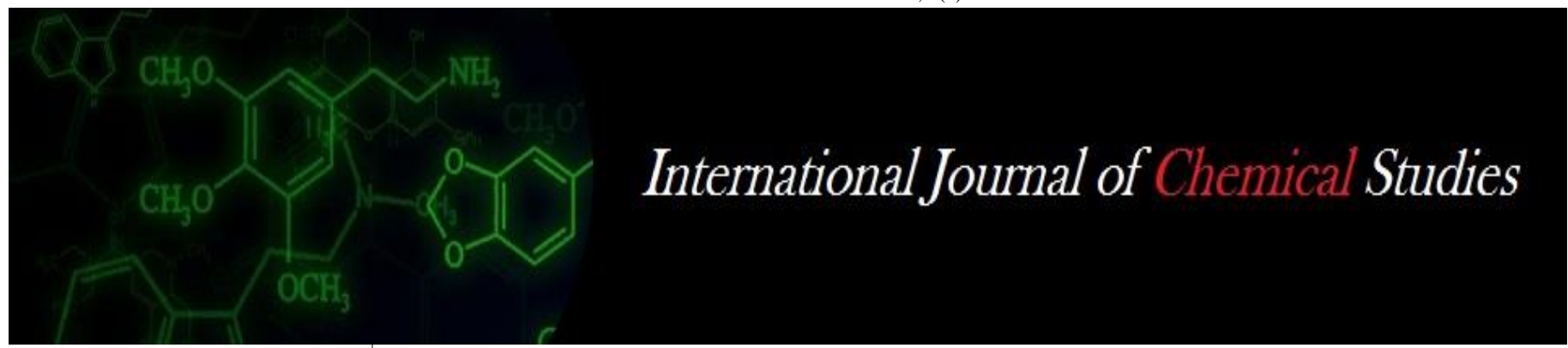

P-ISSN: 2349-8528

E-ISSN: 2321-4902

www.chemijournal.com

IJCS 2020; 8(4): 1890-1895

(C) 2020 IJCS

Received: 01-05-2020

Accepted: 03-06-2020

\section{BC Swain}

Krishi Vigyan Kendra, Odisha University of Agriculture \& Technology, Jajpur, Odisha, India

\section{SP Mishra}

Krishi Vigyan Kendra, Odisha University of Agriculture \& Technology, Jajpur, Odisha India

\section{S Dash}

Krishi Vigyan Kendra, Odisha University of Agriculture \& Technology, Jajpur, Odisha, India

\section{AK Padhiary}

Krishi Vigyan Kendra, Odisha University of Agriculture \& Technology, Sambalpur, Odisha, India
Corresponding Author: SP Mishra

Krishi Vigyan Kendra, Odisha University of Agriculture \& Technology, Jajpur, Odisha, India

\section{Effect of foliar application of nutrients on growth and yield of sesame (Sesamum indicum L.)}

\author{
BC Swain, SP Mishra, S Dash and AK Padhiary
}

DOI: https://doi.org/10.22271/chemi.2020.v8.i4t.9902

\begin{abstract}
The experiment designed to study the effect of foliar application of nutrients on growth and yield of sesame (Sesamum indicum L.) was conducted at the Agricultural Experimental Farm of Calcutta University at Baruipur, in 24 Parganas (South) $\left[88^{\circ} 28\right.$ East longitude, $22^{\circ} 22^{\prime} \mathrm{N}$ latitude and 9.75maltitude] during summer (February-May) in the year 2009. The treatment combination, urea (0.4\%) + KCL $(1.0 \%)$ have best significant effect on physiological and metabolic system of the crops over the control. It might contribute to develop efficient "Sink strength" leading to improved yield attributing character. The yield components and yield have manifested better expression under the application of urea $(0.4 \%)+\mathrm{KCL}(1.0 \%)$ followed by the application of urea $(0.4 \%)+\mathrm{KNO}_{3}(1.0 \%)$. The mean yield under urea $(0.4 \%)+\mathrm{KCL}(1.0 \%)$, urea $(0.4 \%)+\mathrm{KNO}_{3}(1.0 \%)$ and control are $7.85,7.81$ and 6.21 quintal/ha respectively.
\end{abstract}

Keywords: Sesamum indicum, nutrients, Konkan, Baruipur

\section{Introduction}

Oilseeds are the oldest crop in the earth. The crop plays an important role in Indian economy and also entitled the country as a chief producer of oil seeds in the world. Oil seeds constitute the second major agricultural crop in the country next to food grain in the term of tonnage and values. The oilseed production scenario in West Bengal is not better than other oilseed producing states in India. Total area under oilseed cultivation in this state is 5.6 lakh hectares which is about $2.28 \%$ of total oil seed area of the country. On the other side total oilseed production of West Bengal is 4, 50,000 M.T with average yield of $785 \mathrm{~kg} / \mathrm{ha}$. The above production figure is very poor to meet even the oilseed demand of the state itself. About $90 \%$ of the total requirement of oil has to be imported from other states and even from other countries. So there is an urgent need to increase oilseed production in West Bengal and in India. Sesame (Sesamum indium L.) is one of the most important oilseed crops after mustard and it contributed about $30 \%$ of the total oilseed production. It possesses some unique characteristics. This can also be grown well after rice even under delayed sowing. Sesame is a short duration oilseed crop suited most of the intensive cropping system in tropical and subtropical region. In west Bengal sesame is the second important oilseed crop next to mustard and rapeseed.

\section{Materials and Methods}

The experiment designed to study the effect of foliar application of nutrients on growth and yield of sesame (Sesamum indium L.) was conducted at the Agricultural Experimental Farm of Calcutta University at Baruipur, in 24 Parganas (South) [88 28 East longitude, 22 $22^{\prime}$ N latitude and 9.75maltitude] during summer (February -May) in the year 2009.

Topography of land was uniform, medium fertile, clay loamy textured and nearly neutral in reaction. The soil samples from the experimental plots were collected from the depth of $25 \mathrm{~cm}$ prior to the setting up of the experiment.

\section{Design and layout}

The experiment was laid out in RBD with three replications. The treatments were allocated randomly to different plots with the help of random number table. 
Plant selection and treatments: B-67 variety of sesame was used to carry out the experiment. Certified seeds of this variety were used. Spray treatments were:

- Urea $(0.2 \%)$

- Urea $(0.4 \%)$

- $\mathrm{KNO}_{3}(0.5 \%)$

- $\mathrm{KNO}_{3}(1.0 \%)$

- $\mathrm{KCL}(0.5 \%)$

- $\operatorname{KCL}(1.0 \%)$

- $\quad$ Urea $(0.2 \%)+\mathrm{KNO}_{3}(0.5 \%)$

- Urea $(0.4 \%)+\mathrm{KNO}_{3}(0.5 \%)$

- Urea $(0.2 \%)+\mathrm{KNO}_{3}(1.0 \%)$

- Urea $(0.4 \%)+\mathrm{KNO}_{3}(1.0 \%)$

- $\quad$ Urea $(0.2 \%)+\mathrm{KCL}(0.5 \%)$

- Urea $(0.4 \%)+\mathrm{KCL}(1.0 \%)$

- Urea $(0.2 \%)+\mathrm{KCL}(1.0 \%)$

- Urea $(0.4 \%)+\mathrm{KCL}(0.5 \%)$

All treatment were applied separately at 50\% flowering stage.

\section{Details measurement of the lay out}

\begin{tabular}{|c|c|c|}
\hline S. No & Particular & Number/ Area \\
\hline 1. & Total Number of replications & 3. \\
\hline 2. & Total number of treatment combinations & 15. \\
\hline 3. & Total number of plots & 45. \\
\hline 4. & Total number of plots in each replication & 15. \\
\hline 5. & Gross area of the experiment & $617.58 \mathrm{~m}^{2}$ \\
\hline 6. & Net area of the experiment & $450^{2}$ \\
\hline 7 & Net area of the each plot & $10^{2}$ \\
\hline 8. & Width of the bund between plot & $0.3 \mathrm{~m}$. \\
\hline 9 & Width of main irrigation channel & $1.0 \mathrm{~m}$. \\
\hline 10. & Width of sub irrigation channels & $0.6 \mathrm{~m}$. \\
\hline 11 & Width of the whole plot bund & $0.4 \mathrm{~m}$. \\
\hline 12 & Width of the whole plot bund & $0.4 \mathrm{~m}$. \\
\hline 13 & Width of the drainage channel & $1.0 \mathrm{~m}$. \\
\hline
\end{tabular}

The land was given two times ploughing by power tiller followed by laddering and harrowing alternatively. Stubbles and weeds were removed from the field and final preparation of the land was completed 4 days before sowing of seeds. As soon as the soil of the field was brought into appropriate tilth, the field was laid out according to layout plan. B-67 variety of sesame was used for carrying out the experiment. Certified seeds are of these variety were used.

Seed rate: The seed rate of sesame was $6 \mathrm{~kg} / \mathrm{ha}$.

Spacing: In case of sesame plant to plant \& row to row distance was $30 \mathrm{~cm}$.

Application of fertilizer: In case of sesame After final tillage operation the filed was laid out and full dose of nitrogen, phosphorus and potassium as per treatment at the rate of $60 \mathrm{~kg}$ urea /ha $60 \mathrm{~kg} \mathrm{P}_{2} \mathrm{O}_{5} /$ ha and $30 \mathrm{~kg} \mathrm{~K}_{2} \mathrm{O} /$ ha was applied in the form of urea, single super phosphate and muriate of potash respectively, as basal.

Sowing of seeds: The seeds are sown in depth of $4-5 \mathrm{~cm}$ in rows $30 \mathrm{cms}$ apart running to East to West direction.

\section{Observation during Growth Period}

During growth of crops following observations were recorded on 10 randomly selected plants and subsequently at an interval of 20 days after sowing. Those records are as follows:-
1. Periodic plant height $(\mathrm{cm}$.)

2. Number of leaves/ plant

3. Number of pods /plant

4. Dry matter production / plant

Two plants were uprooted randomly per plot for estimation of growth parameters like dry matter production, Leaf Area Index (LAI), Crop Growth Rate (CGR), Relative Growth Rate (RGR). The entire plant samples after taking observations for leaf area were dried in an electrical over at a temp of $80-85^{\circ} \mathrm{C}$ for 48 hours. After completion of drying those samples materials were used for estimating the physiological growth parameters like dry matter production, crop growth rates and relative growth rates etc.

\section{Obesevation during harvesting}

During harvesting, data recorded from each plot is furnished below:

1. Number of capsule / plant.

2. Length of pod.

3. Number of seeds/ capsule.

4. Test weight of seeds (gm.)

5. Seed yield per plot and converted to quintal /ha.

Plant growth analysis was done by the formula proposed by Blackman (1919); Bridge et al, Watson (1947) [11] and Gregory (1917).

\section{Statistical Analysis}

The data thus obtained from the experiment on growth, physiclogical growth parameters, yield component and yield were statically analyzed following the method of analysis of variance as advocated by Panse and Sukhamte (1996), Gomez and Gomez (1980).

\section{Effect of Foliar Spray on Growth Parameters}

Growth and development sesame have been remarkably influenced by foliar spray of different foliar nutrients at $50 \%$ flowering stage. The results on periodic plant height, dry matter production have been presented there under.

Periodic Plant Height: In sesame the plant height has increased continuously and reached maximum just before the harvesting which has been recorded at 90 days after sowing under different level of foliar applications. After foliar application at 45 DAS a significant result has been recorded in plant height character. Both at 60 DAS and 90 DAS foliar application of Urea $(0.4 \%)+\mathrm{KCI}(1.0 \%)$ has given the maximum effect on plant height followed by Urea $(0.4 \%)+\mathrm{KNO}_{3}(1.0 \%)$, which are statistically at par. Among the other treatments KCI $(0.5 \%)$ has given the minimum effect on plant height but the effect is distinctly significant to the control.

Dry Matter Production: The periodic dry matter production per plant presented in table 2 reveals that there has been corresponding increase in dry matter production with subsequent stage of growth. At initial stage of growth up to 30 days, the rate of dry mater accumulation has been rather slow and the effect is non-significant under all treatment. The rate of dry matter production has taken a momentum from 30 days and onwards. The periodic dry matter production reveals that there has been gradual increase in dry matter production till the stage of crop maturity. Among the treatments Urea $(0.4 \%)$ $+\mathrm{KC} 1(1.0 \%)$ has given significantly higher magnitude of dry 
matter both at 60 and 90 DAS $(9.698 \mathrm{gm} / \mathrm{plant}$ and 42.873 $\mathrm{gm} /$ plant respectively) followed by Urea $\left.(0.4 \%)+\mathrm{KNO}_{3}\right)$ $(1.0 \%)$ which are statistically at par.

\section{Physiological Growth Parameters}

Leaf Area Index (LIA): From the result on leaf area index (LAI) under foliar spray of nutrients at $50 \%$ flowering as presented in Table 3, we can reveal that LAI has been increased initially up to maturity stage and after this sage LAI has been increased. The LAI reached to the maximum level when crop is around 70 days old. At 30 DAS there is nonsignificant foliar treatment effect on LAI. But both at 60 DAS and 90 DAS Urea $(0.4 \%)+\mathrm{KC} 1(1.0 \%)$ has given the best effect on LAI followed by Urea $(0.4 \%)+\mathrm{KNO}_{3}(1.0 \%)$.

Crop Growth Rate (CGR): The increase in dry matter per plant per unit time (CGR) under different treatments is shown in table 4. It has increased distinctly from (30-60 DAS) to (60-90 DAS) under all treatments. In this case also Urea $(0.4 \%)+\mathrm{KCI}(1.0 \%)$ has given the best treatment effect on CGR. In the both cases all the treatments are significantly superior to the control.

Relative Growth Rate (RGR): The data on relative growth rate presented in table no 4 reveal the maximum RGR values have been noted during 30-60 DAS and declines during 60-90 DAS of sesame crops. The higher RGR values being 0.01476 g. $\mathrm{g}^{-1}$ day ${ }^{-1}$ in logarithm scale has been noted under the treatment of Urea $(0.4 \%)$ followed by the treatment of Urea $(0.4 \%)+\mathrm{KCI}(0.5 \%)$ and Urea $(0.2 \%)+\mathrm{KNO}_{3}(1.0 \%)$ during 30-60 DAS. Other side during 60-90 DAS the best effect has been noted under the treatment of KCI $(1.0 \%)$ followed by the treatment $\mathrm{KNO}_{3}(1.0 \%)$. During 30-60 DAS there is a nonsignificant effect.

\section{Yield Attributes}

Number of Capsules /Plant: The data presented in table no.5 reveal that maximum number of capsules/plant has been obtained under the treatment of Urea $(0.4 \%)+\mathrm{KCI} 91.0 \%)$ followed by Urea $(0.4 \%)+\mathrm{KNO}_{3}(1.0 \%)$. In this case the foliar treatment has been found significant.

Length of Pod: The result given in table no.5 reveal that the folia spray has been given a significant effect to the control. The best pod length $(2.89 \mathrm{~cm})$ has been obtained under the treatment of Urea $(0.4 \%)+\mathrm{KC} 1(1.0 \%)$. The lowest pod length $(2.13 \mathrm{~cm}$.) can be obtained under the treatment of $\mathrm{KNO}_{3}(1.0 \%)$ which is also significant to the control effect $(1.83 \mathrm{~cm}$.$) .$

Number of Seeds/ Capsule: The data presented in table no. 5 show the foliar treatment effect on number of seeds/ capsule. It can be concluded that the maximum number of seeds per capsule has been obtained under the treatment of Urea $(0.4 \%)$ $+\mathrm{KCI}(1.0 \%)$ significantly followed by Urea $(0.4 \%)+\mathrm{KNO} 3$ $(1.0 \%)$, which are statistically at par.

Test Weight: Form the data listed in table no.5 it can concluded that the foliar treatments have a significant effect on test weight. The maximum test weight (3.77 gm) has been obtained under the treatment of Urea $(0.4 \%)+\mathrm{KNO}_{3}(1.0 \%)$ whereas under control treatment the test weight has been recorded as 2.3 gm only.
Seed Yield: The results obtained in table no.6 on seed yield of sesame show the same tread of significant treatment effect over the control effect. The best seed yield $(7.85 \mathrm{q} / \mathrm{ha})$ has been obtained under the treatment effect of Urea $(0.4 \%)+$ $\mathrm{KC} 1(1.0 \%)$ followed by [Urea $\left.(0.4 \%)+\mathrm{KNO}_{3}(1.0 \%)\right](7.81$ $\mathrm{q} / \mathrm{ha})$, [Urea $(0.4 \%)+\mathrm{KC} 1(0.5 \%)](7.74 \mathrm{q} / \mathrm{ha})$ and so on. Under the control treatment the seed yield has been obtained as $6.21 \mathrm{q} / \mathrm{ha}$.

\section{Discussion}

Sesame has exhibited a typical sigmoid pattern of growth in respect of plant height, irrespective of different foliar treatments. The vegetative growth in height of many crop plants is characterized by a sigmoid pattern. At initial stage of growth, there is no vast difference in plant vigour is influenced through effective absorption of nutrients at critical stage, resulting in enhanced physiological activity and increased plant height (Sarkar et al., 1999) ${ }^{[9]}$. Increase in growth and physiological attributes leads to more production of photosynthetic owing to increased availability, absorption and translocation of nutrients in plants. Application of different foliar nutrients has produced remarkable difference in plant height. The plant height has increased in an increased at up to 60 days and onwards has shown a diminishing rate. This type of growth behavior in plant height has also been reported by Kumar and Yadav (2007) [6]. Dry matter accumulation in plants has followed a sigmoid pattern under different foliar sprays which is characterized by all growth parameters described by Gandadhara et al., (1990). Foliar spray of Urea $(0.4 \%)+\mathrm{KC} 1(1.00 \%)$ has recorded higher dry matter production over the other treatment. The other foliar sprays have also a significant effect on dry matter production over control. Similarly Das and Sarkar in 1981 [3] reported about the effectiveness of foliar spray during $50 \%$ flowering stage in dry matter accumulation. Increase in dry matter production may be accumulated for greater photosynthesis from a relatively larger photosynthetic surface, subsequent translocation and accumulation in different organs of the plants (Ramanujan and Rao, 1971) ${ }^{[8]}$.

Watson (1947) ${ }^{[11]}$ reached the conclusion that variation in leaf area and leaf area index was the main cause of difference in yield. So, leaf area index (LAI) has a great importance on growth parameters as well as crop yield. Leaf area index (LAI) has increased up to 60 days and has declined later because of senescence and leaf fall. Foliar application of urea $(0.4 \%)+\mathrm{KCl}(1.00 \%)$ during $50 \%$ flowering stage has given the best effect on LAI. It may be owing to altered physiological growth of the crop induced by foliar spray through enhanced activities of enzymes and photosynthetic activity. Others high LAI indicates high mobilizable protein at the beginning of reproductive stage which may be synthesized by nitrogen supplied from urea. The crop growth rate (CGR) is directly related with dry matter production. The CGR has increased successfully to 60-90 days of growth. Increase of CGR is due to several factors like shoot growth, number of leaves and dry matter production. Since supply of foliar nutrients has shown pronounced effect on such parameters of growth which in turn has reflected on CGR of sesame. It is evident from the result that CGR is relatively high in case of Urea $(0.4 \%)+\mathrm{KCI}(1.00 \%)$. It is probably due to potent role of $\mathrm{N}$ (from urea) in metabolic activities and on vegetative growth of plants. Other side foliar application may increase LAI due to delay of senescence of leaves. Higher relative 
growth rate (RGR) appears at early stage of growth irrespective of treatments. There are higher RGR values during 30 to 60 days after sowing and it has diminished with the advancement in age of the crop. RGR is the product of NAR and the later is a measure of the size of photosynthesis area. Thus RGR alters with the change in NAR since RGR is a function of NAR.

The yield contributing characters of sesame have been greatly affected by different foliar treatments. Treatment combination of Urea $(0.4 \%)+\mathrm{KCI}(1.00 \%)$ has given best effect followed by Urea $(0.4 \%)+\mathrm{KN} 03(1.0 \%)$ on capsules/plant, length of pod, number of seeds/capsule and test weight of seeds. Increase in these parameters could be ascribed to the overall improvement in plant vigour and production of sufficient photosynthesis. The seed yield of sesame has been increased appreciably with foliar application of nutrients. Foliar fertilization during onset of reproductive growth stage promised to increase yield by avoiding depletion of nutrients in soil and thus foliar spray is a very practical method for increasing seed yield of many crops. (Raman, Garcia and Hanway, 1976) ${ }^{[7]}$.

Among treatment combinations Urea $(0.4 \%)+\mathrm{KCI}(1.0 \%)$ has given the best effect. This may be due to the influence of nitrogen supplied by foliar urea on metabolic process resulting in increased production of photosynthates which resulted in increased seed yield (Dhoble, 1998) ${ }^{[4]}$. Other side $\mathrm{K}+$ ion may enhance photosynthetic activity and facilitate partitioning of photosynthates (Batra, 1982) ${ }^{[1]}$, resulting in higher seed yield. So, it can be concluded that foliar nutrition especially $\mathrm{m}$ the composition of Urea $(0.4 \%)$ and $\mathrm{KCl}$ $(1.00 \%)$ during $50 \%$ flowering has proved effective in increasing sesame yield in Gangetic alluvial soil.

Table 1: Periodic plant heighrt (in $\mathrm{cm}$ ) of seasme under different foliar sprays

\begin{tabular}{|c|c|c|c|}
\hline Foliar spray & 30 DAS & 60 DAS & 90 DAS \\
\hline Urea $(0.2 \%)$ & 12.4 & 52.21 & 65.75 \\
\hline Urea $(0.4 \%)$ & 12.39 & 52.31 & 66.25 \\
\hline $\mathrm{KNO}_{3}(0.5 \%)$ & 12.40 & 50.54 & 63.57 \\
\hline $\mathrm{KNO}_{3}(1.0 \%)$ & 12.39 & 50.65 & 62.35 \\
\hline KCI $(0.5 \%)$ & 12.41 & 51.09 & 64.55 \\
\hline KCl $(1.0 \%)$ & 12.4 & 51.85 & 65.53 \\
\hline Urea $(0.2 \%)+\mathrm{KNO}_{3}(0.5 \%)$ & 12.43 & 53.9 & 66.55 \\
\hline Urea $(0.4 \%)+\mathrm{KNO}_{3}(0.5 \%)$ & 12.40 & 54.22 & 66.82 \\
\hline Urea $(0.2 \%)+\mathrm{KNO}_{3}(1.0 \%)$ & 12.44 & 53.98 & 65.67 \\
\hline Urea $(0.4 \%)+\mathrm{KNO}_{3}(1.0 \%)$ & 12.43 & 54.95 & 66.73 \\
\hline Urea $(0.2 \%)+$ KCl $(0.5 \%)$ & 12.40 & 52.87 & 64.48 \\
\hline Urea $(0.4 \%)+$ KCl $(1.0 \%)$ & 12.45 & 54.98 & 67.85 \\
\hline Urea $(0.2 \%)+$ KCl $(1.0 \%)$ & 12.40 & 54.61 & 66.78 \\
\hline Urea $(0.4 \%)+$ KCI $(0.5 \%)$ & 12.40 & 54.64 & 66.95 \\
\hline Control & 12.39 & 48.34 & 58.33 \\
\hline SEm ( \pm ) & 0.039 & 0.212 & $\mathbf{0 . 1 9 3}$ \\
\hline CD value (0.05) & $0.092(\mathrm{NS})$ & 0.501 & 0.458 \\
\hline
\end{tabular}

Table 2: Periodic dry matter production (gm/plant) of sesame under different foliar sprays:

\begin{tabular}{|c|c|c|c|}
\hline Foliar spray & 30 DAS & $60 \mathrm{DAS}$ & $90 \mathrm{DAS}$ \\
\hline Urea (0.2\%) & 0.303 & 7.575 & 36.531 \\
\hline Urea $(0.4 \%)$ & 0.309 & 8.270 & 38.333 \\
\hline $\mathrm{KNO}_{3}(0.5 \%)$ & 0.293 & 6.953 & 33.123 \\
\hline $\mathrm{KNO}_{3}(1.0 \%)$ & 0.303 & 6.753 & 33.723 \\
\hline KCl $(0.5 \%)$ & 0.295 & 7.287 & 35.343 \\
\hline KCl $(1.0 \%)$ & 0.297 & 7.127 & 37.333 \\
\hline Urea $(0.2 \%)+\mathrm{KNO}_{3}(0.5 \%)$ & 0.323 & 8.370 & 35.433 \\
\hline Urea $(0.4 \%)+\mathrm{KNO}_{3}(0.5 \%)$ & 0.337 & 8.500 & 40.333 \\
\hline Urea $(0.2 \%)+\mathrm{KNO}_{3}(1.0 \%)$ & 0.313 & 8.133 & 33.233 \\
\hline Urea $(0.4 \%)+\mathrm{KNO}_{3}(1.0 \%)$ & 0.529 & 9.432 & 42.569 \\
\hline Urea $(0.2 \%)+$ KCl $(0.5 \%)$ & 0.331 & 8.481 & 38.373 \\
\hline Urea $(0.4 \%)+\operatorname{KCl}(1.0 \%)$ & 0.533 & 9.698 & 42.873 \\
\hline Urea $(0.2 \%)+$ KCl $(1.0 \%)$ & 0.342 & 8.523 & 40.373 \\
\hline Urea $(0.4 \%)+$ KCl $(0.5 \%)$ & 0.345 & 8.973 & 42.030 \\
\hline Control & 0.287 & 6.375 & 27.583 \\
\hline $\operatorname{SEm}( \pm)$ & 0.092 & 0.206 & 0.342 \\
\hline CD value (0.05) & $0.219(\mathrm{NS})$ & 0.487 & 0.809 \\
\hline
\end{tabular}


Table 3: Periodic Leaf Area Index (LAI) of sesame under different concentrations of foliar spray

\begin{tabular}{|c|c|c|c|}
\hline Foliar spray & 30 DAS & 60 DAS & 90 DAS \\
\hline Urea $(0.2 \%)$ & 0.0186 & 0.247 & 0.170 \\
\hline Urea $(0.4 \%)$ & 0.0193 & 0.248 & 0.175 \\
\hline $\mathrm{KNO}_{3}(0.5 \%)$ & 0.0190 & 0.243 & 0.154 \\
\hline $\mathrm{KNO}_{3}(1.0 \%)$ & 0.0185 & 0.242 & 0.153 \\
\hline KCl $(0.5 \%)$ & 0.0191 & 0.244 & 0.158 \\
\hline KCl $(1.0 \%)$ & 0.0191 & 0.245 & 0.160 \\
\hline Urea $(0.2 \%)+\mathrm{KNO}_{3}(0.5 \%)$ & 0.0193 & 0.262 & 0.195 \\
\hline Urea $(0.4 \%)+\mathrm{KNO}_{3}(0.5 \%)$ & 0.0193 & 0.263 & 0.209 \\
\hline Urea $(0.2 \%)+\mathrm{KNO}_{3}(1.0 \%)$ & 0.0197 & 0.251 & 0.186 \\
\hline Urea $(0.4 \%)+\mathrm{KNO}_{3}(1.0 \%)$ & 0.0198 & 0.272 & 0.231 \\
\hline Urea $(0.2 \%)+\mathrm{KCl}(0.5 \%)$ & 0.0193 & 0.262 & 0.208 \\
\hline Urea $(0.4 \%)+\mathrm{KCl}(1.0 \%)$ & 0.0200 & 0.278 & 0.239 \\
\hline Urea $(0.2 \%)+\mathrm{KCl}(1.0 \%)$ & 0.0197 & 0.264 & 0.211 \\
\hline Urea $(0.4 \%)+\mathrm{KCl}(0.5 \%)$ & 0.0192 & 0.266 & 0.211 \\
\hline Control & 0.0175 & 0.176 & 0.117 \\
\hline $\operatorname{SEm}( \pm)$ & 0.0014 & 0.00054 & 0.00073 \\
\hline CD value $(0.05)$ & $0.0034(\mathrm{NS})$ & 0.00129 & 0.00174 \\
\hline
\end{tabular}

Table 4: Crop Growth Rate (C.G.R.) and Relative Growth Rate (R.G.R.)

\begin{tabular}{|c|c|c|c|c|}
\hline \multirow[t]{2}{*}{ Foliar spray } & \multicolumn{2}{|c|}{ CGR(gm/plant/day) } & \multicolumn{2}{|c|}{ RGR(gm/gm/plant/day) } \\
\hline & $30-60$ DAS & 60-90 DAS & 30-60 DAS & 60-90 DAS \\
\hline Urea $(0.2 \%)$ & 0.242 & 0.965 & 0.0466 & 0.0228 \\
\hline Urea $(0.4 \%)$ & 0.265 & 1.002 & 0.0476 & 0.0222 \\
\hline $\mathrm{KNO}_{3}(0.5 \%)$ & 0.222 & 0.872 & 0.0459 & 0.0226 \\
\hline $\mathrm{KNO}_{3}(1.0 \%)$ & 0.215 & 0.899 & 0.0449 & 0.0233 \\
\hline $\operatorname{KCl}(0.5 \%)$ & 0.233 & 0.935 & 0.0464 & 0.0229 \\
\hline $\operatorname{KCI}(1.0 \%)$ & 0.228 & 1.007 & 0.0460 & 0.0240 \\
\hline Urea $(0.2 \%)+\mathrm{KNO}_{3}(0.5 \%)$ & 0.268 & 0.902 & 0.0471 & 0.0209 \\
\hline Urea $(0.4 \%)+\mathrm{KNO}_{3}(0.5 \%)$ & 0.272 & 1.061 & 0.0467 & 0.0225 \\
\hline Urea $(0.2 \%)+\mathrm{KNO}_{3}(1.0 \%)$ & 0.261 & 0.837 & 0.0472 & 0.0204 \\
\hline Urea $(0.4 \%)+\mathrm{KNO}_{3}(1.0 \%)$ & 0.298 & 1.105 & 0.0463 & 0.0218 \\
\hline Urea $(0.2 \%)+\operatorname{KCl}(0.5 \%)$ & 0.272 & 0.996 & 0.0470 & 0.0219 \\
\hline Urea $(0.4 \%)+\operatorname{KCl}(1.0 \%)$ & 0.306 & 1.106 & 0.0420 & 0.0215 \\
\hline Urea $(0.2 \%)+$ KCI $(1.0 \%)$ & 0.273 & 1.062 & 0.0466 & 0.0225 \\
\hline Urea $(0.4 \%)+\mathrm{KCl}(0.5 \%)$ & 0.288 & 1.102 & 0.0472 & 0.0224 \\
\hline Control & 0.203 & 0.707 & 0.0449 & 0.0212 \\
\hline SEm ( $( \pm)$ & 0.0068 & 0.014 & 0.003 & 0.0004 \\
\hline CD value (0.05) & 0.01614 & 0.03304 & 0.00799 & 0.00095 \\
\hline
\end{tabular}

Table 5: Yield attributes of sesame crop under different concentration of foliar spray.

\begin{tabular}{|c|c|c|c|c|}
\hline Foliar spray & $\begin{array}{c}\text { No. of } \\
\text { capsules/ } \\
\text { plant }\end{array}$ & $\begin{array}{l}\text { Length of } \\
\text { pod (c.m.) }\end{array}$ & $\begin{array}{l}\text { No. of } \\
\text { seeds/ } \\
\text { capsule }\end{array}$ & $\begin{array}{c}\text { Test weight } \\
\text { (gm) }\end{array}$ \\
\hline Urea $(0.2 \%)$ & 46.7 & 2.35 & 58.2 & 2.91 \\
\hline Urea $(0.4 \%)$ & 48.9 & 2.37 & 58.9 & 2.95 \\
\hline $\mathrm{KNO}_{3}(0.5 \%)$ & 44.1 & 2.19 & 55.3 & 2.63 \\
\hline $\mathrm{KNO}_{3}(1.0 \%)$ & 42.1 & 2.13 & 54.3 & 2.61 \\
\hline KCl $(0.5 \%)$ & 42.3 & 2.15 & 54.9 & 2.79 \\
\hline KCl $(1.0 \%)$ & 44.3 & 2.23 & 55.9 & 2.85 \\
\hline Urea $(0.2 \%)+\mathrm{KNO}_{3}(0.5 \%)$ & 45.3 & 2.27 & 56.7 & 3.01 \\
\hline Urea $(0.4 \%)+\mathrm{KNO}_{3}(0.5 \%)$ & 55.5 & 2.61 & 64.7 & 3.21 \\
\hline Urea $(0.2 \%)+\mathrm{KNO}_{3}(1.0 \%)$ & 52.3 & 2.49 & 61.9 & 2.58 \\
\hline Urea $(0.4 \%)+\mathrm{KNO}_{3}(1.0 \%)$ & 64.1 & 2.83 & 68.6 & 3.59 \\
\hline Urea $(0.2 \%)+$ KCl $(0.5 \%)$ & 53.3 & 2.55 & 63.9 & 3.18 \\
\hline Urea $(0.4 \%)+$ KCl $(1.0 \%)$ & 64.7 & 2.89 & 69.3 & 3.77 \\
\hline Urea $(0.2 \%)+$ KCl $(1.0 \%)$ & 55.8 & 2.67 & 65.9 & 3.33 \\
\hline Urea $(0.4 \%)+$ KCl $(0.5 \%)$ & 59.3 & 2.69 & 66.7 & 3.35 \\
\hline Control & 37.5 & 1.83 & 52.9 & 2.3 \\
\hline $\operatorname{SEm}( \pm)$ & 1.27 & 0.039 & 1.291 & 0.116 \\
\hline CD value (0.05) & 3.00631 & 0.09234 & 3.058 & 0.27399 \\
\hline
\end{tabular}


Table 6: Yield of sesame crop under different concentrations of foliar spray.

\begin{tabular}{|c|c|c|}
\hline $\begin{array}{c}\text { Treatments } \\
\text { No. }\end{array}$ & Foliar spray & Mean \\
\hline 1 & Urea $(0.2 \%)$ & 7.52 \\
\hline 2 & Urea $(0.4 \%)$ & 7.57 \\
\hline 3 & $\mathrm{KNO}_{3}(0.5 \%)$ & 7.26 \\
\hline 4 & $\mathrm{KNO}_{3}(1.0 \%)$ & 7.19 \\
\hline 5 & $\mathrm{KCl}(0.5 \%)$ & 7.31 \\
\hline$\overline{6}$ & KCl $(1.0 \%)$ & 7.38 \\
\hline 7 & Urea $(0.2 \%)+\mathrm{KNO}_{3}(0.5 \%)$ & 7.42 \\
\hline 8 & Urea $(0.4 \%)+\mathrm{KNO}_{3}(0.5 \%)$ & 7.68 \\
\hline 9 & Urea $(0.2 \%)+\mathrm{KNO}_{3}(1.0 \%)$ & 7.6 \\
\hline 10 & Urea $(0.4 \%)+\mathrm{KNO}_{3}(1.0 \%)$ & 7.81 \\
\hline 11 & Urea $(0.2 \%)+\mathrm{KCl}(0.5 \%)$ & 7.67 \\
\hline 12 & Urea $(0.4 \%)+$ KCl $(1.0 \%)$ & 7.85 \\
\hline 13 & Urea $(0.2 \%)+\mathrm{KCl}(1.0 \%)$ & 7.69 \\
\hline 14 & Urea $(0.4 \%)+\mathrm{KCI}(0.5 \%)$ & 7.74 \\
\hline 15 & Control & 6.21 \\
\hline \multicolumn{2}{|r|}{$\operatorname{SEm}( \pm)$} & 0.017 \\
\hline \multicolumn{2}{|r|}{ CD value $(0.05)$} & 0.04067 \\
\hline
\end{tabular}

\section{Conclusion}

The results thus evidently indicate that application of urea $(0.4 \%)+\mathrm{KCL}(1.0 \%)$ followed by urea $(0.4 \%)+\mathrm{KNO} 3$ $(1.0 \%)$ appears to be most suitable agronomic practices for optimum growth development and yield of sesame on genetic alluvial land of West Bengal.

\section{References:}

1. Batra AI. Response of symbiotic N-Fixan and assimilate portioning of K supply in alfa alfa. Cro Science. 1982; 22:89-92.

2. Brevedan BK, Hodgs HA. Effect of moisture deficit on 14C translocation in corn. Plant Physiol. 1973; 52:436439.

3. Das S, Sarkar AK. Effect of post-flowering foliar spray of potassium nitrate solution on grain filling and yield of rice and wheat, Indian Agriculturist. 1981; 25:267-273.

4. Doble MV. Response of sunflower (Helianthus annus L.) hybrid to nitrogen and phosphorus in rainfed conditions. Indian J. Agron. 1998; 43:138-141.

5. Ghosh DC, Bagdi PR. Yield variation in sesamum sown at montly intervals sub-humid lateritic acid tract of West Bengal. Madras Agriculture Journal. 1986; 73:23-29.

6. Kumar H, Yadav IS. Effect of phosphorus and sulphur levels of growth, yield and quality of Indian mustard (Brassica juncea L.) cultivars. Indian Journal of Agronomy. 2007; 52(2):154-157.

7. Raman Garcia L, Hanway JJ. Foliar fertilization of soyben during the seed-filling period. Agronomy Journal. 1976; 68:653-657.

8. Ramanuja T, Rao JS. Photosynthesis and dry matter production by rice plant growth under different levels of nitrogen. Madras Agricultural Journal. 1971; 58:38-40.

9. Sarkar SK, Chakraborty A, Saha Anita. Effect of foliar application of potassium nitrate and calcium nitrate on ground nut (Arachis hypogaea L.) Indian Journal of Agronomy. 1999; 44(4):809-812.

10. Thatcher RW. A proposed classification of the chemical elements with respect to their functions in plant nutrition. Science. 1934; 79:463-466.

11. Watson DJ. Comparative physiological studios on the growth of field crops. Ann. Bot. N.S. 1947; 11:41-76. 